Mal J Nutr 25(3): 405-411, 2019

\title{
Challenges in a refeeding programme: case report of an Orang Asli boy at household level
}

\author{
Ajlaa A Rasid ${ }^{1}$, Tang Swee Fong ${ }^{2}$, Izandis Mohamad Sayed ${ }^{3}$, Mohd Shazuan \\ Irwan Mohd Shuhaimi ${ }^{4}$, Norazlina Mohd Noh ${ }^{4}$, Sameeha Mohd Jamil ${ }^{1} \&$ Poh \\ Bee Koon ${ }^{*}$ \\ ${ }^{1}$ Nutritional Sciences Programme \& Centre for Community Health Studies, Faculty \\ of Health Sciences, Universiti Kebangsaan Malaysia, 50300 Kuala Lumpur; \\ ${ }^{2}$ Department of Paediatrics, Faculty of Medicine, Universiti Kebangsaan Malaysia \\ Medical Centre, Kuala Lumpur; ${ }^{3}$ Hospital Orang Asli Gombak, Ministry of Health \\ Malaysia; ${ }^{4}$ Hulu Perak District Health Office, Ministry of Health Malaysia
}

\begin{abstract}
Introduction: The refeeding programme in government hospitals is aimed at improving the nutritional status of malnourished children with weight-for-height $\mathrm{z}$-score (WHZ) below -2.0, using special therapeutic food. However, there is a lack of data on the nutritional status of indigenous (Orang Asli) children when they return to the community after hospital discharge. Case presentation: A 3-year-old Temiar boy residing in a tribal village in Hulu Perak was visited to determine his nutritional status following discharge from a refeeding programme in a government hospital. He was admitted to the hospital with a weight of $10.0 \mathrm{~kg}$, height of $85.5 \mathrm{~cm}$ and WHZ of -2.09 . The boy was later discharged weighing $11.0 \mathrm{~kg}$, and with height unchanged at $85.5 \mathrm{~cm}$ and $\mathrm{WHZ}$ of -0.87 . During our visit to the child's home three months after discharge, his weight was $9.5 \mathrm{~kg}$, height $86.0 \mathrm{~cm}$, and WHZ -2.91. Discussion: The management of the case in the hospital was based on the Malnourished Orang Asli Protocols of the hospital. Household food insecurity, feeding and care practices, unhealthy household environment and the lack of communication between hospital and community health services were all identified as risk factors for malnutrition. Conclusion: The recurrence of malnutrition in this child, after successful improvement during hospital stay, highlights the importance of identifying factors that may affect nutritional status after hospital discharge. This knowledge will be beneficial in planning specific interventions, especially for Orang Asli children, living in remote villages.
\end{abstract}

Keywords: Child, indigenous people, malnutrition, refeeding programme

\section{INTRODUCTION}

Malnutrition remains high among indigenous Orang Asli children as shown by recent findings of Wong et al. (2018), where prevalence of stunting, underweight, wasting, and thinness among Orang Asli children $<5$ years were $64 \%, 49 \%$, 14\%, and $12 \%$, respectively. Malnourished Orang Asli children were also at a higher risk of dying before reaching 5 years of age (Wong $\&$ Hussain Imam, 2008). It is recommended that

\footnotetext{
*Corresponding author: Prof. Dr Poh Bee Koon

Chair, Centre for Community Health Studies, Faculty of Health Sciences

Universiti Kebangsaan Malaysia, 50300 Kuala Lumpur

Tel: (6)(03)-92897686/8035; Fax: (6)(03)-26947621; E-mail: pbkoon@ukm.edu.my

doi: https://doi.org/10.31246/mjn-2019-0061
} 
Orang Asli children presenting with a $z$-score of weight-for-height (WHZ) of $<-2.00$ should be brought to a designated health centre/hospital for refeeding (HRPB, 2009). Refeeding usually involves providing special therapeutic food, which consists mostly of ready-to-use therapeutic food or milk-based diets of 75 $\mathrm{kcal} / 100 \mathrm{ml}$ (F75) and $100 \mathrm{kcal} / 100 \mathrm{ml}$ (F100). Post-discharge, these children should receive optimal care to ensure good nutritional status. However, due to poverty and lack of accessibility to health services, malnutrition still recurs among these children, particularly those residing in the interior rural areas (Amar Singh, 2008). As there is little data that is available on the outcomes of refeeding programmes in Malaysia, we wish to highlight the challenges faced during and after refeeding programmes for the Orang Asli community in this case report.

\section{CASE PRESENTATION}

A 3-year old Temiar boy residing in a tribal village in Hulu Perak was visited to determine his nutritional status following his discharge from a refeeding programme in a government hospital. The distance between the hospital and the village was $80 \mathrm{~km}$ and a single journey took approximately an hour and 40 minutes via different modes of transportation (including one hour by car to the jetty on tarred road, 30 minutes by boat and ten minutes by motorcycle from the jetty on gravel and cement-based road). The village was under the operational area of Rancangan Pengumpulan Semula (RPS) or Resettlement Scheme and the nearest static health clinic (Klinik Kesihatan) was located $3.5 \mathrm{~km}$ from the child's house.

The boy was the third-born child among four siblings. There was no information available on his antenatal history from the clinic records as his mother did not seek any antenatal care from the clinic. Neither the birth weight nor the birth length of the child was recorded as this was a home delivery.

The child was breastfed up to two years after his birth and his mother stopped breastfeeding him when she became pregnant with her next child. Complementary feeding was started at six months of age with a commercial cereal-based infant food instead of homemade porridge. His mother had chosen the commercial cereal-based food due to its soft texture and said that the child liked it'.

The family house was entirely built of wood, with no rooms but had a single partition that divided the living and kitchen areas. A gravity feed system, which used gravitational force to draw clean water from higher to lower ground level areas, was used as the main source of water for cooking and laundry. There was no built-in toilet in the house and all sanitary activity and defecation were performed out in the open area, such as at the river or nearby areas.

The mother was a 43-year-old housewife, who weighed $40.9 \mathrm{~kg}$, was $152.8 \mathrm{~cm}$ in height and had a body mass index (BMI) of $17.5 \mathrm{~kg} / \mathrm{m}^{2}$. She was classified as underweight (BMI was $<18.5$ $\mathrm{kg} / \mathrm{m}^{2}$ ) as per the current World Health Organization (WHO) classification of BMI (WHO, 1998). The child's father worked as a rubber tapper with a monthly income of RM400, or RM66.70 per capita which is below the hardcore poverty line of RM539 per household or RM140 per capita for rural areas of Perak (DOSM, 2016). The father was, however, not measured due to his absence during the visit.

The child was admitted for the first time to the hospital's refeeding programme on $10^{\text {th }}$ August 2017 (weight $10.0 \mathrm{~kg}$, height $85.5 \mathrm{~cm}, \mathrm{WHZ}-2.09$ ). At discharge on $15^{\text {th }}$ August 2017, he had the following parameters: weight 
$11.0 \mathrm{~kg}$, height $85.5 \mathrm{~cm}, \mathrm{WHZ}-0.87$. During our visit to the child's home, three months after his discharge, his weight, height and $\mathrm{WHZ}$ were $9.5 \mathrm{~kg}$, $86.0 \mathrm{~cm},-2.91$ respectively. His mid upper arm circumference reading was $111 \mathrm{~mm}$, and he showed signs of kwashiorkor characterised by ascites and bloated stomach as well as changes in hair colour. An immediate referral was made to the nearest clinic and the child was brought to the district hospital for further nutritional management. Following his discharge from the second round of refeeding, his weight, height and WHZ were $10.1 \mathrm{~kg}, 86.0 \mathrm{~cm}$, and -2.10 , respectively. [This value was calculated using an anthropometric software Anthro version 3.2.2 (WHO, 2011) that provided the exact $z$-score value. Conversely, the hospital used a $z$-score table as per protocol (HRPB, 2009), where a height of $86.0 \mathrm{~cm}$ and weight of $10.0 \mathrm{~kg}$ was considered acceptable WHZ].

\section{DISCUSSION}

The Malnourished Orang Asli Protocols of the Paediatrics Department of Hospital Raja Permaisuri Bainun (HRPB, 2009), allows the discharge of a patient from the refeeding programme in district hospital when the patient's WHZ is $\geq$ -2.00. Upon the patient's discharge, the nearest clinic or mobile team in charge of the child's village should be alerted. One of the primary challenges we found in this case was a lack of effective communication between the hospital and the clinic. From the child's health record book, the weight documented at his follow-up visit in the clinic at one month after his first discharge on 11 September 2017 was $10.3 \mathrm{~kg}$. However, we could not find any discharge note on the child's health book at home nor its copy in the clinic. The data on admission and discharge was only available in his hospital records. Therefore, the clinic could not have known that there was a 700 gram decrease in the child's weight within the one month after discharge (discharge weight was $11.0 \mathrm{~kg}$ from the hospital). It was alarming that the child's weight had deteriorated greatly by $13.6 \%$, having decreased from 11.0 $\mathrm{kg}$ (at discharge) to $9.5 \mathrm{~kg}$ (during visit) within three months after discharge, with a WHZ that fell from -0.87 to below -2.00 .

Supplementary feeding was provided to improve the nutritional status of the malnourished child at the clinic. Unfortunately, although the child was previously on the Food Basket Programme, he had defaulted followup for six months. According to the child's health record, it was documented that the mother did not collect his food basket from the clinic due to a lack of transport. We confirmed this during an interview with the mother. The mother also found that it was difficult to walk to the clinic with her four children tagging along. From the clinic's health records, it was noted that the health personnel had conducted several home visits prior to the period of default. However, the house was locked with no one available at home as the mother had reportedly gone fishing at the lake. There was also a report of an incident when the mother ran into the jungle to hide from the nurses. Informal conversation with the neighbours revealed that the mother had hypertension, and thus she was afraid of going to the clinic for her child's follow-up fearing that she would be given treatment instead of her child. Following the second discharge from the refeeding programme, the child was again enrolled in the Food Basket Programme. The mother was advised on the importance of nutritious food and the usage of food basket, including the way to dilute the milk properly. She was also given general advice on health, on matters such as the importance of immunisation 
and attendance for clinic appointments. The child showed slight improvement in his weight gain $(1.0 \mathrm{~kg}$ within seven months). A recent study found that the Food Basket Programme was five times less likely to succeed among Orang Asli children compared to Malay children (Mas-Harithulfadhli-Agus, Hamid \& Rohana, 2018). Therefore, inclusion into other supplementary feeding programmes needs to be considered to further improve this child's nutritional status.

Observation of the family house environment and a look at the sociodemographic factors, revealed that the mother of the boy herself was underweight (BMI $17.5 \mathrm{~kg} / \mathrm{m}^{2}$ ). The vicious cycle of malnutrition was evident in this case, as malnourished mothers are known to give birth to malnourished infants, who then grow into underweight adolescents and adults (Darnton-Hill, Nishida \& James, 2004). Indeed, nutritional deficiencies can adversely impact a child's survival and growth starting from the mother's pregnancy until the child reaches 2 years old (UNICEF, 2009; Black et al., 2013). In this case, given that the pregnancy history was unavailable as the mother had not attend any antenatal care at the clinic, and she was not attended to at delivery by a skilled health worker, there is a high likelihood that she would have had a malnourished child (Hamel et al., 2015). Previous studies have reported that higher proportion of mothers with a malnourished child was themselves underweight, and that general health and nutritional status of mothers at birth affect their offspring (Cheah et al., 2012; Wong, Moy \& Nair, 2014). Apart from that, malnourishment in this case could also be due to poorly spaced pregnancies. The gap between giving birth to her second child and this boy was only 12 months and the gap between him and his youngest sibling was 21 months. Therefore, this child could have been malnourished from early on in his life. However, this could not be confirmed due to the undocumented pregnancy history.

The causality of under-nutrition is multifactorial. Nutritional status is influenced by primary factors, such as household food insecurity, feeding and care practices, unhealthy household environment and inaccessibility of health services, all of which directly influence nutrient intake and the presence of disease (UNICEF, 1990; UNICEF, 2013). Through a face-to-face interview using food insecurity questionnaire (Zalilah \& Ang, 2001), we found that this household experienced child hunger, which is considered the most severe problem arising from household food insufficiency that results in poor diet quality (Zalilah \& Tham, 2002). Child hunger, which is characterised by a low quantity of food consumed by children, occurs only after the adult caregivers in the households have been affected by household food shortages. Coming from a background of hardcore poverty, this finding was in line with the mother's claim saying that, "duit tak cukup, beli sikit-sikit" (Malay), or "...money is not enough, so we only buy a little..." (English translation). This situation directly affected their choices in buying enough food for all household members. However, when there is a shortage in the supply of protein food sources (e.g. when not enough fish caught or when no one can find any protein sources), the Orang Asli men eat first, and the women and children go hungry (Bolton, 1972). The nutritionist in-charge also informed us that the Orang Asli community do not usually talk about food taboos that they practise as they were worried of being scolded by the healthcare professionals. Understanding the root causes of food unavailability and strengthening it with an ethnographical approach that visualises the real practices in their daily 
life, will be beneficial in determining their daily food intake practices.

These malnutrition-related factors directly affected the weight gain of the child. From dietary recall that was conducted during the home visit, we found that the child received $852 \mathrm{kcal}$ (Table 1) from his intake on the previous day. This figure did not meet the $980 \mathrm{kcal} /$ day that the Malaysian Recommended Nutrient Intake (RNI) had recommended for his sex and age (NCCFN, 2017). Energy and macronutrient estimation was calculated using the Nutritionist Pro $^{\mathrm{TM}}$ Diet Analysis software (Axxya Systems, Woodinville, WA, USA). The percentage of macronutrient contribution to total energy intake was $51.8 \%$ carbohydrates, $18.3 \%$ protein and $29.9 \%$ fat. The main contributor to calories were carbohydrate sources, such as rice and sweetened creamer. The sweetened creamer was low in nutrients, even though it contributed to the child's energy intake due to its high sugar content. The protein intake of the child was more than three times the RNI (12 g/day), for a child aged 1-3 years. It was surprising that protein intake appeared to be so high. However, the dietary recall was done during our home visit in November, which coincided with the rainy season when the lake and river nearby had an abundance of fish, which could explain the high protein intake. The occurrence of malnutrition and relapse in this child, however, had occurred three months earlier, and his weight loss was also not detected during the clinic visit. Hence, case management at the clinic was based on routine followup for a child of his age and was not focused specifically on his malnutrition,

Table 1. Dietary findings using 24-hour diet recall taken on the day of visit

\begin{tabular}{|c|c|c|c|c|c|c|c|}
\hline Meal & Food/drinks & Quantity & $\begin{array}{l}\text { Weight } \\
\text { (g) }\end{array}$ & $\begin{array}{c}\text { Energy } \\
\text { (kcal) }\end{array}$ & $\begin{array}{c}\text { Carbohydrate } \\
\text { (g) }\end{array}$ & $\begin{array}{l}\text { Protein } \\
\text { (g) }\end{array}$ & $\begin{array}{l}\text { Fat } \\
\text { (g) }\end{array}$ \\
\hline $9.00 \mathrm{am}$ & Fried rice ${ }^{\dagger}$ & 3 dessert spoons & 75 & 145 & 19.8 & 3.7 & 5.7 \\
\hline Breakfast & $\begin{array}{l}\text { Sweetened } \\
\text { creamer }\end{array}$ & $\begin{array}{l}2 \text { dessert spoons } \\
\text { with } 200 \mathrm{ml} \\
\text { water }\end{array}$ & 18 & 61 & 9.9 & 1.6 & 1.6 \\
\hline $1.00 \mathrm{pm}$ & White rice & 3 dessert spoons & 75 & 125 & 28.9 & 2.2 & 0.1 \\
\hline Lunch & Fried ikan terbul & 4 small pieces & 80 & 116 & 0.4 & 14.3 & 6.4 \\
\hline & $\begin{array}{l}\text { Fried spinach } \\
\text { Plain water }\end{array}$ & 1 scoop & 63 & 50 & 1.2 & 2.3 & 4.0 \\
\hline $\begin{array}{l}5.00 \mathrm{pm} \\
\text { Afternoon } \\
\text { snack }\end{array}$ & $\begin{array}{l}\text { Sweetened } \\
\text { creamer }\end{array}$ & $\begin{array}{l}2 \text { dessert spoons } \\
\text { with } 200 \mathrm{ml} \\
\text { water }\end{array}$ & 18 & 61 & 9.9 & 1.6 & 1.6 \\
\hline $8.00 \mathrm{pm}$ & White rice & 3 dessert spoons & 75 & 125 & 28.9 & 2.2 & 0.1 \\
\hline Dinner & Fried ikan terbul & 2 small pieces & 40 & 58 & 0.2 & 7.2 & 3.2 \\
\hline & $\begin{array}{l}\text { Fried spinach } \\
\text { Plain water }\end{array}$ & 1 scoop & 63 & 50 & 1.2 & 2.3 & 4.0 \\
\hline $\begin{array}{l}9.00 \text { pm } \\
\text { Supper }\end{array}$ & $\begin{array}{l}\text { Sweetened } \\
\text { creamer }\end{array}$ & $\begin{array}{l}2 \text { dessert spoons } \\
\text { with } 200 \mathrm{ml} \\
\text { water }\end{array}$ & 18 & 61 & 9.9 & 1.6 & 1.6 \\
\hline Total & & & & 852 & 110.3 & 39.0 & 28.3 \\
\hline \multicolumn{5}{|c|}{$\%$ total energy intake (TEI) } & 51.8 & 18.3 & 29.9 \\
\hline
\end{tabular}

${ }^{\dagger}$ Fried rice was prepared using basic ingredients (rice, oil, shallots, anchovies and salt). ${ }^{\ddagger}$ Ikan terbul is a type of fish found in rivers and lakes of Tasik Banding, Perak, with weight ranging from $20 \mathrm{~g}$ (small fish) to $80 \mathrm{~g}$ per piece. 
which explained the lack of dietary data from that time period.

There are some limitations in this case report. As recorded in the child's health book, advice was given to the mother, but we were unable to assess the knowledge of the mother and her perception towards malnutrition among her children. This case report highlighted the importance of a mother's knowledge in providing and preparing nutritious food for her child as well as the barriers she faced in attending clinic to seek treatment for herself (hypertension) and her child (malnutrition). The involvement and motivation of both parents are crucial in avoiding a recurrence of malnutrition in the future. There was also a need for good communication between the hospital and the clinic in monitoring a malnourished child's progress. Although the management of this case was done based on the guidelines and the existing standard operating procedure (SOP) for malnourished children, the information shared following the child's discharge from hospital should have been delivered to the clinic or mobile team in-charge of the patients.

\section{CONCLUSION}

In conclusion, the child was still malnourished despite having been successfully treated in the hospital when he was first admitted. The successful nutrition management of a severely malnourished child requires both medical and social needs to be satisfied by all stakeholders. Therefore, identification of the possible causes of the malnutrition, such as economic status, food security, knowledge, attitude and practices that may affect nutritional status, as well as motivators and barriers towards the treatment and follow-up faced by the family, would be beneficial in planning specific interventions for Orang Asli children.

\section{Acknowledgement}

We would like to thank the Director General of Health Malaysia for his permission to publish this article. We thank Universiti Kebangsaan Malaysia (NN-2017-111) and the Ministry of Health Malaysia (NMRR 17-602-34534) for ethical approval, the Jabatan Kemajuan Orang Asli (JAKOA) for written permission to conduct this study, the Hulu Perak hospitals, health district offices and JAKOA district offices for logistical support. Our greatest gratitude goes to the mother of the boy for the cooperation she extended to us to undertake this study.

\section{Authors' contributions}

AAR conceptualised and designed the study, undertook data collection, data analysis, interpretation, and preparation of the draft of the manuscript; TSF advised on the data analysis and interpretation, assisted in the drafting and review of the manuscript; IMS assisted in drafting the manuscript; MSIMS and NMN, conducted data collection in the Hulu Perak district; SMJ, assisted in the drafting and review of the manuscript; PBK, the principal investigator, conceptualised, designed and conducted the study, led the data collection and reviewed the manuscript.

\section{Conflict of interest}

The authors declare no conflict of interest arising from the findings for the reported case and its management.

\section{References}

Amar Singh HSS. (2008). In: Mortality, Morbidity \& Malnutrition in Orang Asli Children. From http:/ / hoag.moh.gov.my/images / pdf_folder / simposium/tujuh.pdf. [Retrieved June 1 2016].

Black RE, Victora CG, Walker SP, Bhutta Z, Christian P, Onis M, Ezzati M, GranthamMcGregor, S, Katz J, Martorell R, Uauy R \& the Maternal and Child Nutrition Study Group (2013). Maternal and child undernutrition and overweight in low-income and middle-income countries. The Lancet 382(9890):427-451.

Bolton JM (1972). Food taboos among the Orang Asli in West Malaysia: a potential nutritional hazard. Am J Clin Nutr 25:789-799.

Cheah WL, Wan Abdul Manan WM, Zabidi Azhar MH \& Chang CT (2012). Factors associated with undernutrition among children in a rural district of Kelantan, Malaysia. Asia-Pac J Publ Hlth 24(2):330-342.

Darnton-Hill I, Nishida C \& James WPT (2004). A life course approach to diet, nutrition and the prevention of chronic diseases. Publ Hlth Nutr 7(1A):101-121. 
DOSM (2016). Pendapatan Garis Kemiskinan (PGK) Mengikut Wilayah. Department of Statistics Malaysia, Putrajaya.

Hamel C, Enne J, Omer K, Ayara N, Yarima Y, Cockcroft A \& Andersson N (2015). Childhood malnutrition is associated with maternal care during pregnancy and childbirth: a crosssectional study in Bauchi and Cross River States, Nigeria. J Publ Hlth Res 4(1):408.

HRPB (2009). Malnourished Orang Asli Protocols. Paediatric Department. Hospital Raja Permaisuri Bainun, Ipoh.

Mas-Harithulfadhli-Agus AR, Hamid NA \& Rohana AJ (2018). Rural child malnutrition and unsuccessful outcome of food basket programme: does ethnicity matter? Ethnic Hlth $1-16$.

NCCFN (2017). Recommended Nutrient Intakes (RNI). National Coordinating Committee on Food and Nutrition, Ministry of Health Malaysia, Putrajaya.

UNICEF (1990). Strategy for Improved Nutrition of Children and Women in Developing Countries. United Nations Children's Fund, New York.

UNICEF (2009). Tracking Progress on Child and Maternal Nutrition: A Survival and Development Priority. United Nations Children's Fund, New York.

UNICEF (2013). Improving Child Nutrition: The Achievable Imperative for Global Progress. United Nations Children's Fund, New York.
WHO (1998). Obesity: Preventing and Managing The Global Epidemic. Report of a WHO Consultation on Obesity. World Health Organisation, Geneva.

WHO (2011). In: WHO Anthro Software (Version 3.2.2, January 2011). From https://www. who.int/childgrowth/software/en/. [Retrieved September 17 2017].

Wong CY, Zalilah MS, Siti Nur'Asyura A, Norhasmah S \& Chin YS (2018). Weight and height faltering in the indigenous children (Orang Asli) of Peninsular Malaysia during the first 2 years of life. Asia Pac J Clin Nutr 27(4):886-892.

Wong HJ, Moy FM \& Nair S (2014). Risk factors of malnutrition among preschool children in Terengganu, Malaysia: a case control study. BMC Publ Hlth 14:785.

Wong SL \& Hussain Imam MI (eds) (2008). A Study on Under Five Deaths in Malaysia in the Year 2006. Ministry of Health Malaysia, Kuala Lumpur.

Zalilah MS \& Ang M (2001). Assessment of food insecurity among low income households in Kuala Lumpur using the radimer/cornell food insecurity instrument - a validation Study. Mal $J$ Nutr 7(1):15-32.

Zalilah MS \& Tham BL (2002). Food security and child nutritional status among Orang Asli (Temuan) households in Hulu Langat, Selangor. Med J Msia 57:1-6. 